\title{
Myśl eklezjologiczna kard. Karola Wojtyły w kazaniach o św. Stanisławie, biskupie i męczenniku
}

„Pragnę opisać Kościół - mój Kościół, który rodzi się wraz ze mną, lecz ze mną nie umiera - ja też nie umieram z nim, który mnie stale przerasta - Kościół: dno bytu mojego i szczyt. Kościół - korzeń, który zapuszczam w przeszłość i przyszłość zarazem, Sakrament mojego istnienia w Bogu, który jest Ojcem [...] Pragnę opisać mój Kościół w człowieku, któremu dano imię Stanisław. I imię to król Bolesław mieczem wpisał w najstarsze kroniki. Imię to mieczem wpisał na posadzce katedry, gdy spłynęły po niej strugi krwi"1.

Powyższe słowa z poematu Stanisław ks. kard. Karola Wojtyły napisanego w roku jego wyboru na papieża mogą być kluczem do wejścia w świat jego związków ze św. Stanisławem, biskupem i męczennikiem, którego był następcą w posłudze biskupiej w Kościele krakowskim ${ }^{2}$. Przestrzenią i istotą tego związku jest żywo pojęta prawda wiary o communicatio sanctorum, która w Duchu Świętym działa w historii, przekracza jej ograniczenia oraz zmienność i umożliwia ubogacającą i wzrastającą więź pomiędzy Kościołem pielgrzymującym na ziemi a uwielbionym w niebie. Więź ta w świadectwie kard. Karola Wojtyły jest niezmiernie dynamiczna i bogata, a uwidacznia się w całokształcie bogactwa jego życia i posługi biskupiej w Krakowie ${ }^{3}$.

Znajduje się ona w swoisty sposób w treści jego kazań wygłoszonych o św. Stanisławie. Temat ten jest przedmiotem licznych omówień historycznych i moralno-filozoficznych. Wymienia się w nim na ogół tryptyk prawd związanych z głoszonymi przez kard. Karola Wojtyłę naukami o św.

${ }^{1}$ K. Wojtyła, Poezje i dramaty, Kraków 1979, s. 103.

${ }^{2}$ Por. B. Kumor, Udział kardynata Karola Wojtyły w „Roku św. Stanisława” w diecezji tarnowskiej, [w:] Karol Wojtyła jako biskup krakowski, red. T. Pieronek, R. M. Zawadzki, Kraków 1988, s. 391.

${ }^{3}$ Por. Karol Wojtyła jako biskup krakowski, dz. cyt.; J. Dyduch, Kanoniczne wizytacje parafii Kardynała Karola Wojtyty, Kraków 2000; Kalendarium życia Karola Wojtyły, opr. A. Boniecki, Kraków 1983. 
Stanisławie jako fundamencie duchowych dziejów Kościoła i ojczyzny, obrońcy ładu moralnego i zwornika jedności narodowej.

Zamierzone studium chce uwypuklić w niej treść ściśle eklezjologiczną podkreślającą niektóre istotne wątki dotyczące natury i posłania Kościoła. Jego zaś wynik nie będzie skutkiem uprzednio założonego na treść kazań teologiczno-eklezjologicznego planu, ale pochodzić będzie z prostego ich odczytania według wyraźnie ukształtowanych w nich myśli kaznodziei, co podkreślą jeszcze liczne cytaty z jego kazań. Na jego treść będzie się składać - w formie dłuższego wstępu - zarysowanie wewnętrznych powiązań kard. Karola Wojtyły ze św. Stanisławem i charakter kazań dotyczących tegoż świętego. W rozwinięciu poruszone zostaną najistotniejsze tematy eklezjologiczne, jak ogólna wizja Kościoła, jego świętość, posługa kapłańska w tajemnicy Chrystusa i Kościoła, relacja Kościoła powszechnego do Kościoła lokalnego i założenia permanentnej odnowy Kościoła.

\section{Charakter kazań o św. Stanisławie}

Swoje kazania kard. Karol Wojtyła wygłaszał z pamięci. Miały one charakter głęboko przemyślanej i przemodlonej improwizacji. Mogło się wydawać - jak wyznaje ich świadek - że był to „rodzaj «głośnego myślenia», czy też dialogu z samym sobą w obliczu Boga i zgromadzonych wiernych. Mówiąc - tworzył. Z wielkim wyczuciem i znajomością psychiki współczesnego człowieka przekonywał go spokojnym wywodem logicznym, perswadował, prosił. Apelował do jego wrażliwości religijnej, intelektualnej i uczuciowej. Przemawiał serdecznie, prosto, bardzo osobiście, nawiązując łatwo bezpośredni z nim kontakt"5. Kazania te były z reguły nagrywane, a następnie przepisywane na maszynie $\mathrm{z}$ taśmy magnetofonowej i przedkładane mu do wglądu. Pozostawione w takiej formie zachowały charakter żywej mowy, w której występujące powtórzenia i użyte zwroty są świadectwem prostoty języka, który z łatwością przekazuje sprawy dotyczące tajemnicy Boga i tajemnicy człowieka. W tej żywej mowie zawarta jest prawdziwa głębia i bogactwo myśli teologicznych oraz kunszt ich wiązania z aktualnością przeżywanego czasu i z jego problemami. Ale jest w tym także i utrudnienie w „łowieniu” wątków teologicznych, co stawia przed badaczami myśli kard. Karola Wojtyły wymóg bardzo uważnej ich lektury.

${ }^{4}$ Por. S. Suski, „Myśląc Ojczyzna”. Problematyka odpowiedzialności za naród w kazaniach, homiliach $i$ przemówieniach biskupa, arcybiskupa i kardynała Karola Wojtyly wygłoszonych w katedrze wawelskiej, Kraków 2001 (mps w Archiwum Papieskiej Akademii Teologicznej w Krakowie, sygn. T-6441), s. 23.

${ }^{5}$ A. Bardecki, Przedmowa, [w:] Ks. Karol Wojtyła - Biskup - Metropolita - Kardynał, Kazania 1962-1978, Kraków 1979, s. 5. 
Bowiem w powtarzających się u niego zwrotach czy zastosowanych tekstach biblijnych pojawiają cię ciągle nowe ujęcia i nowe szczegóły 6 .

Licząca 6140 stron maszynopisu ${ }^{7}$ kaznodziejska spuścizna kard. Karola Wojtyły z lat 1958-1978, tj. od jego konsekracji na biskupa pomocniczego aż do jego wyboru na papieża, jest tematycznie bardzo bogata ${ }^{8}$. Z jej treści można wydobyć także wyraźny wątek związany ze św. Stanisławem, biskupem i męczennikiem ${ }^{9}$. Tematyka ściśle eklezjologiczna kard. Karola Wojtyły natomiast nie doczekała się jak dotąd w polskiej literaturze teologicznej szerszego opracowania. Dotyczy to nie tylko wspomnianej tutaj opcji związanej z jego posługą homiletyczną odnoszącą się do św. Stanisława, ale całości niezwykle bogatej myśli eklezjalnej tego tak bardzo zaangażowanego biskupa i kardynała jako Ojca Soboru i gorliwego pasterza swego Kościoła lokalnego. Jest to tym bardziej godne uwagi, że eklezjologia kard. Karola Wojtyły wzbudziła poważne zainteresowanie u teologów, którzy korzystając z przekładów jego tekstów na znane im języki, wskazują na prawdziwie inspirujące myśli w tym zakresie ${ }^{10}$.

${ }^{6}$ Zwraca na to uwage ks. Andrzej Bardecki w podanym przykładzie na podstawie kazań związanych z ekumenią - por. A. Bardecki, Przedmowa, dz. cyt., s. 5.

${ }^{7}$ Por. A. Bardecki, Przedmowa, dz. cyt., s. 6.

${ }^{8}$ Por. A. Bardecki, Przedmowa, dz. cyt., s. 5n; K. Panuś, Zarys historii kaznodziejstwa w Kościele Katolickim, cz. 2: Kaznodziejstwo w Polsce od oświecenia do XX wieku, Kraków 2001, s. 453-661; K. Wojtyła, Nauczyciel i Pasterz. Listy pasterskie, komunikaty, zarzadzenia 1959-1978, opr. M. Jagosz, Rzym 1987; J. Hennelowa, Nota wydawcy, [w:] Ks. Karol Wojtyła, „Aby Chrystus się nami postugiwat”, Kraków 1979, s. 483; J. Dyduch, Przedmowa, [w:] Kazania i przemówienia kardynała Karola Wojtyty o kapłaństwie, opr. J. Dyduch, Kraków 1995, s. 5; K. Wojtyła, „Oto Matka Twoja”, Częstochowa 1979; Kazania w sanktuarium kalwaryjskim, Kalwaria Zebrzydowska 1982; Wybór kazań nowohuckich oraz homilie Jana Pawła II w Krakowie-Nowej Hucie, Kalwaria Zebrzydowska 1989.

${ }^{9}$ Por. J. Wolny, Sesje historyczne w okresie pasterzowania kardynała Karola Wojtyly, [w:] Karol Wojtyła jako biskup Krakowski, red. T. Pieronek, R. M. Zawadzki, Kraków 1988, s. 488.

${ }^{10}$ H. J. Pottmeyer, znany niemiecki teolog i członek Międzynarodowej Komisji Teologicznej, wskazuje w myśli eklezjologicznej kard. Karola Wojtyły na profetyczną przenikliwość (prophetische Hellsichtigkeit) w odczytaniu głównych idei Vaticanum II i ich wdrażaniu w życie Kościoła przez biskupa krakowskiego i papieża Jana Pawła II. Swoje uwagi odnosi do książki kard. Karola Wojtyły U podstaw odnowy. Studium o realizacji Vaticanum II (Kraków 1972, 1988² 2003³), na której aktualność treści wskazał w swoim referacie pt. Dal Sinodo del 1985 al. Grande Giubileo dell'anno 2000, [w:] Comitato Centrale del Grande Giubileo dell'anno 2000, Il Concilio Vaticano II. Recezione e attualità alla luce del Giubileo, Milano 2000, s. 17nn, wygłoszonym 27 lutego 2000 roku w Watykanie podczas sympozjum na temat Soboru Watykańskiego II. Swoją opinię na temat aktualności myśli teologicznej kard. Karola Wojtyły powtórzył w referacie pt. Die Kirche - Volk Gottes, Communio, Sakrament. Konkurrenz oder Kongruenz ekklesiologischer Leitideen? wygłoszonym w Papieskiej Akademii Teologicznej w Krakowie 9 maja 2003 roku - zob. H. J. Pottmeyer, Die Kirche - Volk Gottes, Communio, Sakrament. Konkurrentz oder Kongruenz ekklesiologischer Leitideen?, [w:] Servo veritatis. 
Trudno byłoby jednoznacznie wyselekcjonować zbiór monotematycznych kazań o św. Stanisławie, biskupie i męczenniku. I choć czas ich wygłaszania zbiega się ze zbliżającą się i obchodzoną 900. rocznicą pasterzowania świętego biskupa męczennika, co naturalnie skłania do jego wspomnienia, to jednak rozważanie o nim kard. Karol Wojtyła zawsze wiąże z jakimś aktualnym wydarzeniem w życiu Kościoła. Stanisławowa treść pochodzi nade wszystko z kazań wygłoszonych przy grobie świętego w katedrze wawelskiej z racji odbywających się tam święceń diakonatu i kapłaństwa, jak i z tytułu corocznego uroczystego wspomnienia jego święta 8 maja i związanej z nim nowenny i procesji z Wawelu na Skałkę. Nie wszystkie też kazania tam wygłoszone zawierają, poza wspomnieniem miejsca grobu świętego, odniesienie do jego postaci ${ }^{11}$. Rozważania homiletyczne podczas celebry liturgii z racji świąt Bożego Narodzenia, Objawienia Pańskiego, Triduum Paschalnego czy innych były w całości poświęcone tym obchodom ${ }^{12}$.

W swoich rozważaniach kard. Karol Wojtyła odczytuje krakowskiego pasterza z XI wieku tak w perspektywie historycznej, jak i - co zawsze podkreśla - w teologicznej obecności jego świadectwa. Ta pierwsza, historyczna perspektywa była bardzo istotna. Uważał, że jest ona konieczna dla osadzenia teologicznej istoty posługiwania i świadectwa św. Stanisława. Dlatego też w swoich kazaniach zawsze zwracał uwagę na głosy historyków, i to nawet tych nieprzychylnych, którzy swoimi niesprawdzonymi tezami wyrządzali krzywdę samemu świętemu, a przez to fałszowali dzieje Kościoła w Polsce i Polski. Dla dogłębnego zbadania historii bpa Stanisława ze Szczepanowa, jak też i dziejów diecezji krakowskiej, bp Karol Wojtyła w roku 1963, jeszcze jako wikariusz kapitulny, wydał polecenie zbadania relikwii św. Stanisława, zwłaszcza zbadania jego czaszki ${ }^{13}$. W 1971 roku zwrócił się do historyków Papieskiego Wydziału Teologicznego w Krakowie o przygotowanie publikacji naukowej związanej ze sprawą i kultem św. Stanisława, a także o zorganizowanie ogólnopolskiej sesji naukowej na temat Dzieje Kościoła polskiego i Krakowa w XI wieku, która miała miejsce pod koniec listopada 1972 roku $^{14}$. W następnym, 1973 roku w maju w domu

Materiały międzynarodowej konferencji dla uczczenia 25-lecia pontyfikatu Jego Światobliwości Jana Pawta II, red. S. Koperek, S. Szczur, Kraków 2003, s. 273-286.

${ }^{11}$ Np. kazanie z 14 września 1975 roku w całości poświęcił złotym jubilatom kapłańskim: ks. E. Florkowskiemu i ks. S. Czartoryskiemu - por. Akta Kardynała Karola Wojtyły w Archiwum Kurii Metropolitalnej w Krakowie III 12, s. 263nn (dalej: AKKW E).

${ }^{12}$ Wyjątek stanowi kazanie na Boże Narodzenie 1965 roku w katedrze wawelskiej poświęcone w całości zakończonemu dziełu Soboru Watykańskiego II - por. AKKW E III 2, s. 63-67.

${ }^{13}$ Por. J. Wolny, Sesje historyczne w okresie pasterzowania kardynała Karola Wojtyly, art. cyt., s. 488.

${ }^{14}$ Por. tamże, s. 490n. 
arcybiskupów krakowskich miała miejsce sesja pt. Factum św. Stanisława, zaś w listopadzie tegoż roku w kapitularzu kapitulnym na Wawelu sesja historyków sztuki pt. Ikonografia św. Stanisława, męczennika i biskupa krakowskiego $^{15}$. W maju 1978 roku kard. Karol Wojtyła zorganizował sesję naukową na temat Św. Stanisław - biskup i męczennik w literaturze polskiej. Nosił się z zamiarem zwołania kolejnych sesji poświęconych osobie św. Stanisława w polskiej muzyce oraz w dziejach Polski średniowiecznej ${ }^{16}$.

Wspomniana perspektywa historyczna nie jest tylko tłem dla rozważań teologicznych. Pomaga mu w odnalezieniu człowieka w jego własnej historii, w której spotyka on wiarę Kościoła. Historia biskupa Stanisława jest świadectwem działania łaski wiary w człowieku, która czyni go sposobnym do pełni dojrzałości w Jezusie Chrystusie oraz do obrony człowieka i jego godności aż do heroicznego oddania za niego własnego życia ${ }^{17}$. Historia nie jest tylko - przez swoje przykłady - nauczycielką życia. W ludziach, którzy związali się całkowicie z absolutem Boga i Jego miłością, staje się przestrzenią spotkania człowieka z Bogiem w przestrzeni wiary Kościoła w mocy Ducha Świętego. Historia przypomina postać świętego biskupa przez ciągle trwającą dynamikę wiary i jego pasterskiego oddania. Przez św. Stanisława jak „przez nikogo innego [...] wkroczył Bóg ze swoją mocą w życie Ludu Bożego żyjącego na polskiej ziemi"18. Historia człowieka związanego z Kościołem jest historią zbawienia. W świadectwie świętego biskupa kaznodzieja odnajduje ciągle ten sam Kościół, który jest wspólnotą dzieci Bożych ponad latami historii - chodzi o prawdę świętych obcowania, która rozpoczyna się w konkretnym wszczepieniu człowieka w Kościół, a wypełnia się w dojrzewaniu przez wiarę, nadzieję i miłość, potwierdzoną przez męczeńską krew, w życiu wiecznej chwały z Bogiem. Nie waha się mówić o „łasce historii”, która bogactwo świadectwa św. Stanisława czyni aktualnym dzisiaj ${ }^{19}$. O tym historiozbawczym uaktualnieniu św. biskupa męczennika usłyszeli 7 maja 1972 roku pielgrzymi zebrani na miejscu jego urodzenia w Szczepanowie: „Minęło 900 lat, wymieniło się tyle pokoleń, ale Kościół jest ten sam, Lud Boży jest ten sam; ten sam, z którego kiedyś wyrósł, dziecię Szczepanowa, owoc tej ziemi wyrósł i wrósł raz na zawsze. Taka jest bowiem tajemnica Kościoła jako wspólnoty dzieci Bożych; taka jest tajemnica Kościoła jako świętych obcowanie, że człowiek, który w nim

${ }^{15}$ Por. tamże, s. 491.

${ }^{16}$ Por. M. Winowska, T. Matras, Sprawozdanie z sesji naukowej (Kraków 29-30 V 1978), „Analecta Cracoviensia” 11 (1979), s. 661.

${ }^{17}$ Por. K. Wojtyła, Kazania 1962-1978, Kraków 1980, s. 58n.

${ }^{18}$ Tamże, s. 59.

${ }^{19}$ Por. AKKW E III 3, s. 25. 
i z niego wyrasta, wrasta w tę wspólnotę Ludu Bożego zarówno przez swoje życie ziemskie, jak potem - i to się w szczególny sposób do Stanisława odnosi - przez życie wieczne, przez życie chwały, do którego dojrzał przez swą wiarę, nadzieję i miłość, przez swoją męczeńską krew"20. Te dwie perspektywy, historyczna i teologiczna, skierowane na spotkanie Boga z człowiekiem w Kościele, wyznaczają nieodmiennie metodę myśli homiletycznej kard. Karola Wojtyły, w tym także kazań o św. Stanisławie.

\section{Kościół wspólnotą troski o zbawienie każdego człowieka}

W swoich listach pasterskich i homiliach Stanisławowych kard. Karol Wojtyła posługiwał się najczęściej dwiema kategoriami Kościoła: lud Boży i Mistyczne Ciało Chrystusa. Były to dla niego pojęcia komplementarne ${ }^{21}$. Używał ich zamiennie w stosunku do nazwy Kościół, wierni, wspólnota wierzących itp. bez podawania głębszej analizy wewnętrznej treści. Treść tę podawał w swoich rozważaniach, jakie wygłaszał w różnych kościołach Krakowa w przerwach pomiędzy kolejnymi sesjami odbywającego się Soboru Watykańskiego II, a także i w licznych publikacjach dotyczących eklezjologii odbywającego się w tym czasie Vaticanum $I I^{22}$.

Perspektywa eklezjologiczna ma charakter narastający, co uwidocznione jest przez nowe myśli w homiliach podczas obchodów związanych ze św. Stanisławem. To ubogacenie treści następuje też przez nawiązywanie do wydarzeń w życiu Kościoła katolickiego w Polsce i w świecie. Jej zaś fundamentem jest ewangeliczna nauka Pana Jezusa o Dobrym Pasterzu (J 10, 11-18), z której Kościół, owczarnia Dobrego Pasterza, jawi się jako wspólnota troski o zbawienie każdego człowieka. W kazaniu 8 maja 1959 roku $^{23}$ przybliża św. Stanisława w jego staraniach o pozyskanie króla Bolesława przez przedstawienie jego pasterskiej odwagi, której skutkiem jest miłująca troska. Pasterska odwaga zaś rodzi się z wiary w jedynego Dobrego Pasterza, który oddał życie za wszystkich bez wyjątku² ${ }^{24}$ W tym obrazie św. Stanisława mógł wydobyć trzy elementy dobrego pasterza: „umiejętność

${ }^{20}$ K. Wojtyła, Kazania 1962-1987, dz. cyt., s. 60.

${ }^{21}$ Por. List do Duchowieństwa z okazji Ingresu, „Notificationes” 5-6 (1964), s. 99n; List do Duchowieństwa z okazji 600-lecia konsekracji katedry wawelskiej, „Notificationes” 5-6 (1964), s. 102; Kazanie wygłoszone w kościele św. Anny w Krakowie 12.01.1964, AKKW E III 1, s. 6-9; Przemówienie na zjeździe dekanalnym w Kalwarii Zebrzydowskiej 23.01.1964, AKKW E III 1, s. 26nn; Kazanie na Skałce 12.05.1968, AKKW E III 5, s. 91n; Kazanie w katedrze podczas święcenia subdiakonów 08.05.1972, AKKW E III 9, s. 141.

${ }^{22}$ Syntezę eklezjologiczną Vaticanum II podał kard. Karol Wojtyła w swojej książce U podstaw odnowy. Studium o realizacji Vaticanum II, Kraków 2003³, s. 78-134.

${ }^{23}$ Por. AKKW E III 17/3, s. 1-4.

${ }^{24}$ Por. tamże, s. 2. 
widzenia duszy ludzkiej taką, jaka ona naprawdę jest, z całym realizmem - umiejętność widzenia duszy ludzkiej wedle myśli Bożej i Bożego planu, wedle miary Bożej miłości - wreszcie do głębi związane właściwe z Bogiem i Bogiem Stwórcą i Bogiem Odkupicielem - oto są trzy elementy [...] pierwiastki duszy pasterza" 25 .

15 lat później, w 1974 roku, po głębokim doświadczeniu szkoły Ducha Świętego, którą okazał się dla kard. Karola Wojtyły Vaticanum $I I^{26}$, powie o tej trosce pasterskiej św. Stanisława, której dziedzictwo ma znaleźć odbicie w owocach aktualnie trwającego synodu archidiecezji krakowskiej: „Tę troskę mamy wszyscy we wspólnocie Kościoła. Kościół jest wspólnotą troski o zbawienie. Tym jest nasz Kościół cały [...]. Kiedy się tu schodzimy, jest z nami Jego troska, ta zbawiająca, ta która ogarnia całego człowieka; która widzi człowieka w całej prawdzie, ponieważ odczytuje jego rzeczywistość z Boga, który jest Ojcem, który jest Synem, który jest Duchem Świętym”27. Kościół jawi się jako wspólnota troski o zbawienie każdego człowieka. Jego pasterze tę troskę podejmują, czego najlepszym przykładem stał się św. Stanisław. On zauważył wilka, jaki się zakradł w jego czasach do Kościoła, „i podjął z nim zmaganie na miarę swoich czasów. Nie łudźmy się, że wilk w naszych czasach nie zbliża się do owczarni. Chyba jest o wiele groźniejszy [...] Dlatego musimy w całej wspólnocie odnaleźć dziedzictwo św. Stanisława, a przez to odnaleźć dziedzictwo Dobrego Pasterza. W tym kierunku prowadzi nas światło Ducha Świętego, przyjęte na Soborze Watykańskim II"28.

Idea Kościoła i jego pasterzy, których cechą jest płynąca z miłości Dobrego Pasterza troska o zbawienie każdego człowieka, zaczęła kształtować się w formę pewnej sumy teologiczno-pastoralnej, którą uwydatniło przesłanie Soboru Watykańskiego II. W ostatnim roku swego pasterzowania w Kościele krakowskim w swoim kazaniu 8 maja 1978 roku z racji plenarnego zgromadzenia synodu archidiecezji krakowskiej kard. Kardynał Wojtyła kolejny raz nawiązał do fundamentu rozważań Stanisławowych: „Na św. Stanisława pozwala i nakazuje nam Kościół w swojej liturgii patrzeć poprzez przypowieść o Dobrym Pasterzu. Jest to właściwie spojrzenie wzajemne: patrzymy na Stanisława [...] poprzez Chrystusa, Dobrego Pasterza. Patrzymy poniekąd na Chrystusa, Dobrego Pasterza, poprzez Stanisława [...] Jedno spojrzenie w drugim się dopełnia"29. Treść tej przypowieści

${ }^{25}$ Tamże, s. 3.

${ }^{26}$ Por. K. Wojtyła, U podstaw odnowy..., dz. cyt., s. 5n.

${ }^{27}$ Kazanie wygłoszone w Katedrze Wawelskiej w czasie Mszy św. podczas III Zebrania Plenarnego Synodu Archidiecezji Krakowskiej 08.05.1974 r., „Notificationes” 5-6 (1974), s. 99.

${ }^{28}$ Tamże, s. 99.

${ }^{29}$ AKKW E III 15, s. 104. 
można by określić jednym słowem: „troska. Pasterz to jest ten, który się troska [...] każda twórcza troska płynie z miłości [...] i dlatego jest twórcza: tworzy dobro, osłania przed złem" ${ }^{30}$. Dla zaakcentowania tego przekonania kaznodzieja przenosi myśl na naukę Soboru Watykańskiego II, „który dostarczył nam współczesnej wykładni Ewangelii Chrystusowej, szczególną uwagę zwrócił na przypowieść o Dobrym Pasterzu. Można by powiedzieć, że cała nauka tego Soboru jest zbudowana na gruncie przypowieści o Dobrym Pasterzu. Nie na próżno nazywa się ten sobór pastoralnym albo duszpasterskim. To wszystko, co czytamy na kartach jego dokumentów, to jest wielkie wezwanie do twórczej troski. Do troski o człowieka, o człowieka każdego bez wyjątku: o człowieka współczesnego i przyszłego, o człowieka uwikłanego we wszystkie konflikty współczesności, człowieka, który nosi w sobie głębokie napięcia i sprzeczności" 31 . Tę to troskę ma przejąć przez dzieło kończącego się synodu Kościół krakowski. Tej twórczej troski „wspólnoty zespolonej w Sercu Dobrego Pasterza" nie da się już cofnąć, bo wytyczył ją na dziejowe drogi Polaków św. Stanisław ${ }^{32}$.

Ujęcie Kościoła jako wspólnoty troski o zbawienia każdego człowieka nie było hasłem kaznodziei czy duszpasterza, ale zakorzenioną teologicznie w Ewangelii pełną ideą Kościoła w jego naturze i posłaniu. Naturą tą była miłość Jezusa Chrystusa, Dobrego Pasterza, potwierdzona przez przykład św. Stanisława i innych pasterzy, zaś adresem posłania był człowiek i to każdy bez wyjątku. Ta eklezjologia troski uwidoczniła się w sposób powszechny przez posługiwanie papieskie Jana Pawła II.

\section{Wspólnota Kościoła przestrzenią dojrzewania wiary}

Św. Stanisław ze Szczepanowa jest dla kard. Karola Wojtyły jako biskupa nade wszystko nauczycielem wiary ${ }^{33}$. W kazaniu na Skałce 12 maja 1968 mówił: „Wiele jest zdań z Ewangelii, które mówią o konieczności żywej wiary. Mówi nam o tym wreszcie czcigodna głowa św. Stanisława: jego wiara była żywa aż do śmierci. Żył swoją wiarą. I chciał, ażeby wszyscy, którzy tę wiarę wyznają, żyli wiarą, którą wyznają. I chciał i żądał, ażeby król Bolesław Śmiały, który tę wiarę wyznaje i daje temu dowody, że jest wyznawcą wiary Chrystusowej, że jest synem Kościoła, żył wedle tej wiary. Zwłaszcza on, zwłaszcza król [...]. Tego żądał Stanisław od króla Bolesława. Kierując się świadomością żywej wiary to swoje dążenie przypieczętował

\footnotetext{
${ }^{30}$ Tamże, s. 104.

${ }^{31}$ Tamże, s. 105.

${ }^{32}$ Tamże, s. 106.

${ }^{33}$ Por. Homilia w Szczepanowie 07.05.1972, [w:] K. Wojtyła, Kazania 1962-1978, dz. cyt., s. 58.
} 
krwią męczeńską"34. Uświadomienie wiary jako Bożego daru jest bowiem według kaznodziei fundamentem prawdziwego otwarcia się osoby ludzkiej na dar Objawienia. Ona uzdalnia człowieka do pełnej akceptacji swego powołania i sensu istnienia przez całkowite powierzenie siebie $\mathrm{Bogu}^{35}$. W cytowanym już kazaniu ze Szczepanowa wygłoszonym 7 maja 1972 roku, a więc w przeddzień uroczystej inauguracji Synodu Archidiecezji Krakowskiej, jaka odbyła się następnego dnia w katedrze wawelskiej, kard. Karol Wojtyła wskazał na dwa cele swojego pielgrzymowania do miejsca narodzenia św. Stanisława: chciał odnowić wiarę pasterza-męczennika w świetle nauczania Vaticanum II, a także spotkać człowieka, który narodził się z wiary Kościoła i jako pasterz według tej wiary kształtował powierzony sobie Kościół lokalny. Tak sformułowany cel wskazuje na szczególną świadomość eklezjalną kard. Karola Wojtyły. Rodzi się ona z wiary zakorzeniającej człowieka w życiu Bożym i czyni go sposobnym do pełni ludzkiej dojrzałości w Jezusie Chrystusie oraz do obrony człowieka i jego godności aż do heroicznego oddania za niego własnego życia. Świadomość ta jest kontynuacją zamysłu metropolity krakowskiego skierowanego na zasadnicze pytanie dotyczące osobowego (personalnego) spotkania człowieka z Bogiem w przestrzeni wiary Kościoła.

O tej dojrzałej wierze mówił nade wszystko w homiliach wygłaszanych w katedrze wawelskiej z racji udzielanych tam święceń diakonatu i kapłaństwa. Dojrzałe i wolne „tak” wypowiedziane wobec Dobrego Pasterza przez kandydatów do święceń ma być owocem ich dojrzałej wiary. Jej skutkiem zaś może być zdolność oddania całego życia dla Chrystusa i Jego Kościoła na wzór św. Stanisława, biskupa i męczennika ${ }^{36}$. Kard. Karol Wojtyła nie używał słowa „świętość” czy „dążenie do świętości”. Mówił wprost o dojrzewaniu do rozpoznania i przyjęcia „wymiaru łaski i Tajemnicy", jakim jest sakramentalny udział w jedynym kapłaństwie Jezusa Chrystusa: „Chrystus chce dzisiaj wyrazić w Was siebie, swoje Kapłaństwo, swoją pasterską troskę. Chce Was niejako sobą zapieczętować w Duchu Świętym"37. A konkretny wyraz znajdzie to w całym posługiwaniu kapłańskim: w głoszeniu słowa, w szafarstwie sakramentów i w pasterskiej trosce o każdą duszę w Chrystusowej owczarni ${ }^{38}$. W odniesieniu zaś do świeckich taką dojrzałość wiary nazywa świadomym katolicyzmem ${ }^{39}$.

\footnotetext{
${ }^{34}$ AKKW E III 5, s. 52-53.

${ }^{35}$ Por. K. Wojtyła, U podstaw odnowy, dz. cyt., s. 12 n.

${ }^{36}$ Por. AKKW E III 10, s. 49n.

${ }^{37}$ AKKW E III 11, s. 267.

${ }^{38}$ Por. tamże, s. 267.

${ }^{39}$ Por. AKKW E III 17/6a, s. 6.
} 
Na szczególną uwagę zasługuje podkreślenie sposobu, w jaki kaznodzieja z konfliktu pomiędzy biskupem Stanisławem a królem Bolesławem wydobył najistotniejszą treść teologiczną, którą jest dojrzała świętość i wchodzenie na droge jej pozyskiwania. W kazaniu z 8 maja 1959 roku wygłoszonym w katedrze wawelskiej do kapłanów i alumnów seminarium duchownego nawiązał do opinii historyków, którzy zajmowali się wyjaśnieniem konfliktu pomiędzy św. Stanisławem a królem Bolesławem ${ }^{40}$. Opinie te były różne i miały też wielorakie motywacje. Kaznodzieja postawił dalszą kwestię: „A co w tej sprawie mówi Kościół [...] Kościół każe nam w uroczystość św. Stanisława czytać Ewangelię o Dobrym Pasterzu" ${ }^{41}$. Kaznodzieja w jej świetle wyjaśnia istotę tego wydarzenia sprzed 900 lat. Jest to spojrzenie inne niż historyków. Jego zaś wyjściem jest wewnętrzne życie pasterza-biskupa, dla którego upominany przez niego król nie był wrogiem ani przedmiotem nienawiści: „musiał być przedmiotem miłości i przedmiotem troski” ${ }^{42}$. Miłość ta ma swoje źródło w wierze w Dobrego Pasterza, który oddaje swoje życie za wszystkich bez wyjątku. Z niej też wyłania się zarys teologii postawy pasterza oparty na trzech elementach: ludzka, pełna realizmu umiejętność widzenia duszy ludzkiej taką, jaka ona jest naprawdę; prześwietlenia tego ludzkiego spojrzenia myślą i planem Boga wedle miary Jego miłości i wiązanie z Bogiem, i Bogiem Stwórcą, i Bogiem Odkupicielem, całej rzeczywistości życia i posługi ${ }^{43}$. Z takiego ujęcia zrodziła się specyficzna soteriologia posługiwania biskupiego: „Jeżeli zapłatą za śmierć św. Stanisława na Skałce była pokuta Bolesława, to wystarczyło [...] w porządku nadprzyrodzonym. Biskup został spłacony, został spłacony w sposób jakiś doczesny, widzialny, bo przecież o to Mu chodziło [...], aby zdobyć duszę ludzką, aby nawrócić człowieka bez względu na to, że człowiek ten był królem"44.

Wątek sporu pomiędzy biskupem Stanisławem a królem Bolesławem został przeniesiony na płaszczyznę teologiczną i w kolejnych homiliach nieustannie pogłębiany. 8 lat później w kazaniu na Skałce (14 maja 1967) abp Karol Wojtyła powiedział: „Kiedy jednak rozpamiętywamy świadectwo św. Stanisława, musimy rozpatrzeć je do końca: musimy widzieć w nim Biskupa i króla. Biskup dał świadectwo stojąc i opadając przy ołtarzu: ale i król dał świadectwo, przywdziewając pokutny wór”45. Stanisław wrósł

${ }^{40}$ Por. AKKW E III 17/3, s. 1-4. Będzie o tym przypominał w następnych homiliach - por. AKKW E III 4, 43nn.

${ }^{41}$ AKKW E III 17/3, s. 1.

42 Tamże, s. 2.

${ }^{43}$ Por. tamże, s. 3.

${ }^{44}$ Tamże, s. 4.

${ }^{45}$ Kazanie na Skatce, 14.05.1967 r., AKKW E III 4, s. 74. 
w swój lud przez męczeństwo, a król przez podjęcie pokuty i dzieło nawrócenia. Obydwa świadectwa są w pełni chrześcijańskie i obydwa kształtowały historię narodu i Kościoła.

Tak sformułowane „pojednanie” biskupa Stanisława i króla Bolesława należy do całego dziedzictwa Kościoła katolickiego w Polsce. Jest oparte na odważnej wierze i miłości pasterskiej biskupa, ale też oparte jest na wierze króla, który przez pokutę wyznaje tę wiarę. Taka wiara została wpisana w rodzący się Kościół i stała się szczególnym podłożem dla jej dojrzewania $^{46}$. To świadectwo męczeństwa i pokuty będzie towarzyszyć Kościołowi w Krakowie przez całe wieki, a jego znakiem stanie się coroczna procesja z Wawelu na Skałkę.

W swojej analizie świadectwa św. Stanisława kard. Karol Wojtyła dotknął także nadużywanego pojęcia traditor. To tak wieloznaczne określenie opisał też w perspektywie Ewangelii o Dobrym Pasterzu, który daje swoje życie za owce: „Kronikarz tamtych czasów powiedział o nim [św. Stanisławie - przyp. J. M.]: traditor. Przypisał mu traditio [...]. Wiemy jednakże z innego jeszcze źródła, aniżeli Kronika Galla Anonima, wiemy z dzisiejszej Ewangelii, że jest taka traditio, która w szczególny sposób zobowiązuje każdego pasterza, wyróżnia go i określa jako dobrego pasterza [...]. Tak dał tradidit Jezus Chrystus. Tak dał tradidit św. Stanisław"47. Słowa te, wypowiedziane do członków polskiego episkopatu zebranego na uroczystej konferencji z racji 900. rocznicy pasterzowania św. Stanisława w katedrze wawelskiej (27 czerwca 1972) kaznodzieja uzupełnił wezwaniem pastoralno-moralnym: „I my wszyscy spadkobiercy i dziedzice biskupa Stanisława ze Szczepanowa, chodzimy jakoś w opinii tego ogólnego określenia: Pastores et Traditores. I nie lękamy się określenia: traditores [...], jak on się nie uląkł [...] skoro jesteśmy pastores" ${ }^{48}$. O tym wydaniu siebie św. Stanisława, które stało się doskonałym komentarzem do przeczytanej Ewangelii o Dobrym Pasterzu dodał: „Na św. Stanisława pozwala i nakazuje nam Kościół w swojej liturgii patrzeć poprzez przypowieść o Dobrym Pasterzu [...] patrzymy na Stanisława, Pasterza Kościoła Krakowskiego, poprzez Chrystusa Dobrego Pasterza. Patrzymy też poniekąd na Chrystusa, Dobrego Pasterza, poprzez Stanisława ze Szczepanowa [...]. Jedno spojrzenie w drugim się dopełnia"49. Z tej treści teologicznej wskazuje na praktyczną

\footnotetext{
${ }^{46}$ Por. Kazanie na Skatce, 12.05.1968 r., AKKW E III 5, s. $91 \mathrm{n}$.

${ }^{47}$ Kazanie w katedrze w czasie uroczystej sesji Konferencji Episkopatu Polski, 27.06.1972 r., AKKW E III 9, s. 232-233.

48 Tamże, s. 233.

${ }^{49}$ AKKW E III 15, s. 104.
} 
postawę pasterza, jak to było w kazaniu z 1959 roku, którą jest twórcza troska płynąca z miłości do powierzonej trzody ${ }^{50}$.

Trudne i niemożliwe do wyjaśnienia historyczne zdarzenia dotyczące św. Stanisława i jego sporu z królem Bolesławem kard. Karol Wojtyła rozwiązał na płaszczyźnie teologicznej. Na tych poplątanych ścieżkach historii i życia poszczególnych ludzi Bóg wypełnia swoją obietnicę zbawienia, a losy ludzi i ich postawa jako męczenników czy pokutników niosą wielką łaskę - ich uświęcenie. Bo „w rozroście tego historycznego drzewa, którym jest Kościół polski, brały udział różne moce [...] w jakiś szczególny sposób [...] te Boże moce, które zostały objawione w Stanisławie [...], w Jego życiu, pasterzowaniu, świadectwie i męczeńskiej śmierci” ${ }^{51}$. I choć jest „jakaś ludzka historia tworzona przez ludzi”, to jest też ,jakaś Boża historia [...] tworzona przez Boga w ludziach: Gesta Dei per homines" 52.

W przytoczonych powyżej słowach kard. Karola Wojtyły ani razu nie pada termin „świętość” czy „dążenie do świętości”. Jest natomiast mowa o dojrzałości wiary, która dobrego pasterza biskupa Stanisława uzdalnia do mężnej walki o nawrócenie króla Bolesława. Jej przejawem i owocem jest świadectwo męczeństwa pasterza oraz łaska pokuty danej królowi.

\section{Tajemnica kapłaństwa w tajemnicy Chrystusa i Kościoła}

Kościół jako lud Boży i Mistyczne Ciało Chrystusa wyraża się szczególnie przez posługę sakramentalną swoich pasterzy, którzy realizują misję Chrystusa-Pasterza. Ich władza „nie jest niczym innym jak troską o dusze i odpowiedzialnością za nie"53. Kard. Karol Wojtyła wyznaje swoje miejsce w Kościele jako jego biskup. Kościół jest dla niego najpierw Matką, dzięki której urodził się do tej szczególnej posługi. Swój ingres do katedry (4 marca 1964) przeżywa jako narodziny: „Otóż jeżeli tu dzisiaj staję na progu tej katedry, jeżeli całuję ten ołtarz i zasiadam na tronie biskupów i metropolitów krakowskich, to mam przede wszystkim świadomość narodzin [...] to życie On [Jezus Chrystus] dał naszej Matce. On - Oblubieniec Niebiański, Boski, Syn Boży - dał naszej Matce, Kościołowi Świętemu, tę dziwną moc rodzenia; dlatego właśnie jest Matką [...] bo rodzi" ${ }^{54}$. Kościół Matka rodzi go jako pasterza na wzór Jezusa Chrystusa, który jest Dobrym Pasterzem. To stanowi całą istotę jego posługiwania Kościołowi: zrodzony

\footnotetext{
${ }^{50}$ Por. tamże.

${ }^{51}$ AKKW E III 9, s. 234.

${ }^{52}$ AKKW E III 17/6a, s. 6.

${ }^{53}$ K. Wojtyła, Nauczyciel i Pasterz, Rzym 1987, s. 87.

${ }^{54}$ K. Wojtyła, Kazania 1962-1987, dz. cyt., s. 14.
} 
przez Kościół-Matkę pasterzem na wzór Jezusa Chrystusa dla pasterzowania Kościołowi krakowskiemu ${ }^{55}$.

Szerzej eklezjologiczne wątki w kazaniach Stanisławowych dotyczących kapłaństwa w tajemnicy Chrystusa i Kościoła, występują w homiliach kard. Karola Wojtyły wygłaszanych do kandydatów do diakonatu i kapłaństwa. Jakby naturalną ich ideą przewodnią był przykład pasterskiego oddania świętego biskupa ${ }^{56}$. Dzień święceń jest nazwany zawsze wielkim dniem Kościoła krakowskiego, w którym kolejne roczniki alumnów seminarium duchownego są posyłane jako diakoni i kapłani do posługi w Kościele ${ }^{57}$. Wspólnym tematem tych pouczeń podczas udzielania sakramentu kapłaństwa było przedstawianie wielkiej jego godności, która ma swoje źródło w jedynym kapłaństwie Jezusa Chrystusa. Św. Stanisław zaś stawał się dla nowo wyświęcanych kapłanów szczególnym świadkiem wierności kapłańskiej i pasterskiej oraz więzi z Chrystusem i Kościołem ${ }^{58}$.

Pośród tych kazań - ze względu na temat niniejszego rozważania - wyróżnia się to wygłoszone w czasie święceń prezbiteratu 20 maja 1973 roku ${ }^{59}$. W słowach kaznodziei Kościół jawi się jako wspólnota świadków Chrystusa, której naturą jest posłanie do wszystkich ludzi z Jego Ewangelią. Aby to posłanie było owocne, nowi kapłani muszą świadomie i z całą odwagą wejść w samo centrum tajemnicy Jezusa Chrystusa Odkupiciela.

Ta tajemnica Chrystusa wyrażana jest w dwóch obrazach Wieczernika ${ }^{60}$. Jest to najpierw Wieczernik Eucharystii, gdzie Chrystus „podzielił się z ludźmi, z Apostołami, swoim kapłaństwem”61. Jest to następnie Wieczernik Zmartwychwstania, gdzie Chrystus dał swoim uczniom moc odpuszczania grzechów, tj. podzielił się z nimi swoim odkupieniem, które przez nich ma wchodzić w cały lud Boży i rodzić coraz to nowe ofiary duchowe ${ }^{62}$. Te tajemnice Wieczernika, pomiędzy którymi stoi krzyż i zmartwychwstanie Jezusa Chrystusa, stają się ich tajemnicami i zadaniem: to czyńcie na moją pamiątkę $^{63}$. Te wydarzenia stanowią „środek tajemnicy Jezusa Chrystusa,

\footnotetext{
${ }^{55}$ Por. tamże, s. 15.

${ }^{56}$ Por. Kazania i przemówienia kardynała Karola Wojtyly o kapłaństwie, dz. cyt.

${ }^{57}$ Por. AKKW E III 11, s. 264.

${ }^{58}$ Por. tamże, s. $265 \mathrm{nn}$.

${ }^{59}$ Por. AKKW E III 10, s. 92-94.

${ }^{60}$ Por. tamże, s. 92.

${ }^{61}$ Tamże.

${ }^{62}$ Por. tamże.

${ }^{63}$ Por. tamże.
} 
[...] samo centrum Jego Boskiego i ludzkiego działania”, którego uczestnikami staną się w ludzie Bożym nowo wyświęceni kapłani ${ }^{64}$.

W tę wielką tajemnicę Jezusa Chrystusa mogą wejść tylko przez Kościół, a wprowadzić ich chce sam kaznodzieja jako ich biskup i szafarz sakramentu kapłaństwa. A ten Kościół jako wejście do tajemnicy Chrystusa jawi się w słowach kard. Karola Wojtyły następująco:

„-Wchodzicie tutaj przez Kościół. Przez Kościół, który jest nie tylko Bożym Ludem, ale zarazem jako Boży Lud, Ciałem mistycznym Chrystusa;

- Wchodzicie tutaj przez Kościół, to znaczy przez chrzest, w którym narodziliście się do nowego, Bożego życia w Waszym ludzkim życiu w Kościele;

- Wchodzicie tutaj przez Kościół, to znaczy przez bierzmowanie, którym zostaliście umocnieni, i już wówczas posłani na podobieństwo Apostołów;

- Wchodzicie tutaj przez Kościół, to znaczy przez Wasze chrześcijańskie rodziny. Przez Waszych spracowanych ojców i pełne poświęcenia matki;

- Wchodzicie tutaj przez Kościół, to znaczy przez Wasze parafie, w których wciąż się uprawia Bożą rolę i wciąż się także zbiera owoce winnicy Pańskiej;

- Wchodzicie tutaj przez Kościół krakowski, którym ma w swoich dziejach tego Biskupa i Męczennika, wobec którego relikwii teraz się znajdujemy;

- Wchodzicie tutaj przez Kościół żyjący na naszej polskiej ziemi od tysiąca lat, Kościół doświadczony i wypróbowany, Kościół uświęcający i walczący, walczący o prawo ducha, walczący o prawa człowieka, o prawa rodziny, o przyszłość ludzkości;

- Przez ten Kościół Boży, który żyje na całym okręgu ziemi, który zmaga się z szatanem, ze światem w tym ujemnym tego słowa znaczeniu. Zmaga się z ludzką słabością nieustannie, w ciągu każdego stulecia i każdego pokolenia, w każdym bez wyjątku człowieku - w każdym z nas;

- Wchodzicie tutaj przez ten Kościół, który jest Oblubienicą Jezusa Chrystusa, Małżonką Baranka Bożego; i wciąż, jak Oblubienica wierna, jak Małżonka płodna, rodzi Mu dzieci. Jesteście zrodzeni. Zrodzeni w sakramencie chrztu; zrodzeni w bierzmowaniu, ażeby się dzisiaj jeszcze raz narodzić z Ducha Bożego, Chrystusowego, w sakramencie kapłaństwa"65.

Tekst ten, stanowiący z pewnością wielką kaznodziejską improwizację eklezjologiczną kard. Karola Wojtyły, można nazwać summarium nauki

\footnotetext{
${ }^{64}$ Tamże, s. 93-94.

${ }^{65}$ Tamże, s. 93. Autor artykułu zmienił celowo - przy zachowaniu literowej wierności - formę cytowanego tekstu, aby wydobyć bogactwo jego treści.
} 
o Kościele w jego najgłębszej tajemnicy sakramentalnej. Kościół jawi się bowiem jako żyjący z niewyczerpanych źródeł sakramentów zbawienia, a równocześnie przejawiający się w życiu poszczególnych ludzi i wspólnot i wypełniający niezmordowanie swoje posłanie wobec człowieka i świata. Siłą jego posłania jest miłość oblubieńcza, która jest dziewiczo wierna i macierzyńsko płodna w budowaniu królestwa Bożego. Tak przedstawiony Kościół może być właściwym wejściem, drogą w zbawcze tajemnice Jezusa Chrystusa. W takim Kościele Chrystus chce zastawiać Wieczernik Eucharystii i udzielać przebaczenia w bogactwie i mocy swego Ducha.

Taki obraz tajemnicy Chrystusa i Kościoła jest przypomniany kandydatom do przyjęcia sakramentu kapłaństwa służebnego, której to tajemnicy staną się uczestnikami przez apostolskie nałożenie rąk i modlitwę konsekracyjną do Ducha Świętego ${ }^{66}$. Istota, natura i sposób posłania kapłańskiego wynika z istoty i natury tajemnicy Chrystusa i Kościoła. Będą posłani, aby te tajemnice zbawienia Chrystusa uobecniać w ludzie Bożym i w każdym człowieku' ${ }^{67}$.

\section{Relacja pomiędzy Kościołem powszechnym a Kościołem lokalnym}

Prawda ta, zakorzeniona w jedności i powszechności Kościoła, w wyznawanych w Credo jego znamionach, w nauce kard. Karola Wojtyły wyrażona została w kontekście aktualnych wydarzeń w życiu Kościoła, a przez to zyskała na głębi i autentyczności. Ma jakby trzy obszary doświadczeń. Patrząc wstępująco, tj. od pojedynczego Kościoła lokalnego, który jest w Krakowie, dotyczy więzi Kościołów lokalnych w obrębie jednej metropolii, następnie Kościoła katolickiego w Polsce i Kościoła powszechnego z biskupem Rzymu jako jego widzialną głową.

Kard. Karol Wojtyła zauważył wielką szansę pogłębienia więzi pomiędzy Kościołami lokalnymi w obrębie metropolii krakowskiej przez dzieło synodu krakowskiej prowincji kościelnej ${ }^{68}$. Jubileusz 900 -lecia pasterzowania św. Stanisława stał się dla niego pretekstem do zaproszenia biskupów z Kościołów krakowskiej metropolii, aby podjąć wspólne dzieło synodu tej prowincji kościelnej ${ }^{69}$. Jego treścią miała stać się wspólna recepcja Soboru Watykańskiego II, jak to wyraził w kazaniu w Szczepanowie 7 maja 1972 roku: „A sięgamy tutaj do tego wspaniałego źródła, jakim dla Kościoła i ludzkości naszych cza-

\footnotetext{
${ }^{66}$ Por. tamże, s. 94.

${ }^{67}$ Por. AKKW E III 11, s. 267.

${ }^{68}$ Por. T. Pieronek, Na drodze do metropolitalnej wspólnoty, [w:] Karol Wojtyta jako biskup Krakowski, dz. cyt., s. 395-449.

${ }^{69}$ Por. K. Wojtyła, Kazania 1962-1987, dz. cyt., s. 56.
} 
sów stała się nauka Soboru Watykańskiego II [...], która Kościołowi naszych czasów dała współczesny wyraz, a zarazem nowe zakorzenienie w Ojcu, Synu i Duchu Świętym. [...] to wzbogacenie i pogłębienie wiary [...] pragniemy w szczególny sposób osiągnąć w siedmioleciu rocznicy św. Stanisława. Takie są nasze zamierzenia; tak ta rocznica wielka, dziewięćsetna, przemówiła do naszej duszy i takim wyraziła się wnioskiem i postanowieniem" "70.

W swoich homiliach wygłoszonych w katedrze na Wawelu kard. Wojtyła wielokrotnie wspominał o chęci ożywienia patronatu św. Stanisława w Kościele w Polsce. Wiązał ten patronat ze św. Wojciechem i Maryją Królową Polski, których przedstawia jako polski tryptyk ${ }^{71}$. Swoim męczeństwem św. Stanisław wyraził w pełni to, co zasiał św. Wojciech ${ }^{72}$. Gdyż, jak przekonywał kaznodzieja, w zasięgu promieniowania jego męczeństwa „dokonywało się przedziwne dzieło duchowego scalenia [...] naszego narodu [...] Jest rzeczą ze wszech miar uzasadnioną, jest rzeczą nieodzowną, ażebyśmy przy tym grobie zjednoczyli się na Tysiąclecie Chrztu [...] cały Episkopat, Duchowieństwo, cały Lud Boży naszej Archidiecezji, a pośrednio całej Polski" 73 . Publicznie też wyznawał, że dla tej jedności Kościoła, narodu, a także dla wzrostu czci św. Stanisława, jak sobie na to zasłużył, będzie zapraszał nadal do Krakowa biskupów i wiernych. Takim ważnym wydarzeniem była uroczysta sesja Konferencji Episkopatu Polski w katedrze wawelskiej 27 czerwca 1972 roku, gdzie do zebranych biskupów wypowiedział słowa: „I można rzec, że Jego sukcesja trwa przez dziewięć już wieków we wszystkich biskupach polskich; nie w znaczeniu kanonicznym, ale w znaczeniu moralnym i w znaczeniu duchowym. Wszyscy jesteśmy dziedzicami i spadkobiercami tamtego Biskupa i Męczennika sprzed dziewięciu wieków: Stanisława ze Szczepanowa"74. Szczególnym znakiem jedności biskupów Kościoła katolickiego w Polsce stał się ich liczny udział w corocznej procesji z Wawelu na Skałkę z racji uroczystości ku czci św. Stanisława. Metropolita krakowski mógł z radością gospodarza dziękować im, wobec wielkich rzesz pielgrzymów, za przybycie do Krakowa. Pewną tradycją stał się także udział prymasa kard. Stefana Wyszyńskiego, który podczas mszy świętej na Skałce wygłaszał homilię ${ }^{75}$.

${ }^{70}$ Tamże, s. 57-58.

${ }^{71}$ Por. Kazanie $w$ katedrze wawelskiej na rozpoczęcie nowenny przed św. Stanisławem, 29.04.1968 r., AKKW E III 5, s. 34.

${ }^{72}$ Por. Przemówienie Księdza Metropolity Karola Wojtyty w Katedrze Wawelskiej, 08.05.1963 r., AKKW E III 17/6a, s. 4.

${ }^{73}$ Kazanie wygłoszone w katedrze wawelskiej na rozpoczęcie nowenny przed św. Stanisławem, 29.04.1966 r., AKKW E III 3, s. 24.

${ }^{74}$ AKKW E III 9, s. 232.

${ }^{75}$ Por. np. Stowo na Skatce, 14.05.1972 r., AKKW E III 10. 
Najbardziej wyraźny ślad w wyżej wymienionych homiliach pozostawiły nawiązania kaznodziei do więzi, jaka istnieje pomiędzy Kościołem lokalnym w Krakowie a Kościołem powszechnym z biskupem Rzymu. Dodatkowym, a przy tym bardzo istotnym powodem wyakcentowania tego związku stał się udział biskupa Karola Wojtyły w Soborze Watykańskim II. W języku jego homilii nabrało to dodatkowego zabarwienia. W kazaniu w katedrze na godzinę przed wyjazdem na II Sobór Powszechny do Rzymu 5 października 1962 roku wskazał, że wchodzi na drogę prowadzącą „od grobu św. Stanisława do grobu św. Piotra. I to jest szczególny powód wzruszenia, bo przecież tą drogą z Krakowa, od grobu św. Stanisława do grobu św. Piotra chadzano już przez całe stulecia. To jest gościniec naszej historii. Ten gościniec połączył nas z wielką kulturą zachodu, z wielką kulturą narodów [...], gościniec pasterzy, biskupów, świętych [...] połączył nas z królestwem Bożym na ziemi”" "Wr. Wyruszający na Sobór biskup jest świadom wielkiej odpowiedzialności zarówno za dziedzictwo Piotra, jak i Stanisława. Sam zaś zwołany sobór postrzega jako możliwość przeżycia włączenia Kościoła w Krakowie w jeden wielki nadprzyrodzony organizm Kościoła Jezusa Chrystusa $^{77}$. Do treści tego kazania nawiązał w przemówieniu w katedrze wawelskiej 25 grudnia 1965 roku, w którym też dokonał pierwszego podsumowania zakończonego soboru i swojego w nim udziału: „, Kościół św. Stanisława w Komunii Kościoła Chrystusowego [...]. Kiedy w początkach października 1962 roku - jako wikariusz kapitulny archidiecezji krakowskiej odjeżdżałem na Sobór, odjeżdżałem stąd, tuście mnie żegnali. I odjeżdżając stąd, mówiłem [...], że ruszam od grobu św. Stanisława do grobu św. Piotra. Podkreślałem to, bo te wielkości się uzupełniają, są jakoś proporcjonalne - jakoś się dopełniają [...]. I ten Kościół polski, a zwłaszcza ten mój umiłowany Kościół krakowski [...] zabrałem z sobą do grobu św. Piotra, do tej wielkiej powszechności Kościoła Chrystusowego, która się na Soborze ukazała i wyraziła. I tam, w tej wielkiej powszechności, w tej wielkiej jedności, w tej wielkiej komunii wszystkich na świecie Kościołów, nasz Stanisławowy, Krakowski Kościół był [...]. Był i uczestniczył i tworzył odnowę Kościoła"78. Na tym soborowym spotkaniu Kościoła stary Kościół krakowski i tysiącletni Kościół w Polsce potwierdzał się w powszechności Kościoła Chrystusowego wśród wszystkich Kościołów z całego świata i tam też odnalazł się na nowo. „Tam, na Soborze, przeżywaliśmy na co dzień ową communio - jedność z wszystkimi Biskupami całego globu ziemskiego. Tam, na Soborze codziennie prowadziliśmy dialog wewnętrzny. I ten dialog

\footnotetext{
${ }^{76}$ AKKW E III 17/4, s. 4.

${ }^{77}$ Por. tamże, s. 5.

${ }^{78}$ AKKW E III 17/11, s. 6.
} 
wewnętrzny Kościoła prowadzony przez z górą dwa tysiące Biskupów był odświeżający, stanowił podstawę odnowy Kościoła. We własnym doświadczeniu [...] wewnętrznego dialogu Kościoła szukaliśmy zasady, która może być podstawą odnowy ludzkości"79.

Kard. Karol Wojtyła zauważył też w swojej homilii, że biskupi polscy przeżywali już tam w Rzymie, pośród zgromadzonego episkopatu światowego, „nasze Tysiąclecie”. A jednym z owoców tego doświadczenia była wymiana listów między biskupami polskimi a niemieckimi ${ }^{80}$. Sobór ten przez codzienne, przez trwające wiele miesięcy spotkania z biskupami z całego świata, ta communio episcoporum umacniała światową communio ecclesiarum. „To była wielka łaska dla naszego Kościoła Krakowskiego, polskiego, Stanisławowego"

Powyższe szkicowo zaznaczone fakty, co wynika z języka homiletycznego kaznodziei, kryją w sobie wielkie bogactwo treści teologicznej o Kościele dotyczącej wzajemnej relacji zarówno pomiędzy Kościołami lokalnymi, jak i między Kościołami lokalnymi a Kościołem powszechnym. Relacje te otrzymały wielką szansę oczyszczenia i pogłębienia przez wykorzystanie jubileuszy kościelnych, jak tysiąclecie chrztu Polski, jubileusz pasterzowania św. Stanisława, a nade wszystko przez dar Soboru Watykańskiego II. Dlatego też w przytaczanym powyżej kazaniu, pierwszym po zakończeniu soboru, słuchacze zebrani w katedrze wawelskiej w uroczystość Bożego Narodzenia 1965 roku usłyszeli, że to całe dzieło powszechnego spotkania pasterzy z biskupem Rzymu na czele ,przynosimy od grobu św. Piotra do grobu św. Stanisława, cały Sobór, całą odnowę Kościoła”, aby przy grobie św. Stanisława zweryfikować życie według jego treści ${ }^{82}$. Wspomina przy tym powrót bł. Wincentego Kadłubka z Soboru Laterańskiego IV (1215) oraz owocność podjętych przez niego posoborowych reform w życiu Kościoła w Polsce. I dodaje: „I my także wracamy, Biskupi, ażeby dokonać odnowy Kościoła w Polsce, ażeby dokonać odnowy polskiego Kościoła w Kościele powszechnym [...]. Jakże wielkie pragnienie tej odnowy przynosimy do grobu św. Stanisława, jakże wielkim pragnieniem tej odnowy pragniemy Was - my biskupi - zapalić" ${ }^{33}$. Podstawową myślą Vaticanum II według

\footnotetext{
${ }^{79}$ Tamże, s. 7.

${ }^{80}$ Por. tamże, s. 9 n.

${ }^{81}$ Tamże, s. 10.

82 Tamże, s. 10.

${ }^{83}$ AKKW E III 2, s. 66. W podobny sposób przedstawiał bp Karol Wojtyła swoją drogę do Rzymu na konsystorz (29 czerwca 1967), gdzie został kreowany kardynałem - por. AKKW E III 4, s. 84; Homilia w czasie ingresu kardynalskiego do katedry wawelskiej, tamże, s. 96nn.
} 
kard. Karola Wojtyły był postulat wzbogacenia wiary ${ }^{84}$. Patronem jej dojrzałości był św. Stanisław i dlatego z nim chciał związać dzieło recepcji soboru w Kościele krakowskim. W kazaniu na Skałce 12 maja 1968 roku powie: „Przecież wiara została wpisana w dzieje ludu Bożego na naszej ziemi tym płodnym, ofiarnym, kapłańskim męczeństwem św. Stanisława. To jego myśl zasadnicza, która mnie - jako biskupa Waszego - głęboko nurtuje. I korzystam z tej sposobności, że jesteśmy tutaj razem, ażeby tę myśl ujawnić, myśl o zadaniach, które wkłada na nas wielka rocznica śmierci, a przed tym jeszcze rocznica pasterzowania św. Stanisława" ${ }^{85}$.

\section{Trwały wysiłek o ubogacenie wiary}

Fundamentem trwałości Kościoła, jego niezniszczalności jak też i nieomylności, tj. przekazywania Objawienia Bożego w całej jego prawdzie, jest jego świętość, która przejawia się w dojrzałej wierze. Jest ona także w życiu i świadectwie chrześcijan pierwszym, najważniejszym i najskuteczniejszym znakiem jego posłania w świecie. W codziennej posłudze uświęcania człowieka i świata Kościół natrafia na ciągle nowe wyzwania i potrzebuje środków dla ich podjęcia i rozwiązania zarówno dla pożytku wiernych, jak i dla zdynamizowania owocności swego posługiwania. Na podobieństwo apostołów Jezusa Chrystusa i ich przykładowego działania soborowego (por. Dz 15, 1-35) Kościół korzystał ze spotkań pasterzy i współodpowiedzialnych z nimi dla oczyszczenia i umocnienia swego życia i posłania. Spotkania soborowe i synodalne stały się trwałym instrumentem permanentnej reformy i odnowy Kościoła. Bp Karol Wojtyła jako ojciec Soboru Watykańskiego II dostrzegł w tym to najprostsze, jak też i najbardziej sprawdzone działanie Kościoła lokalnego, jakim był synod. Jeśli jednak dzieło synodu miało wydać trwałe owoce i na stałe wejść głęboko w życie Kościoła, musiało się stać podobne do siły świadectwa św. Stanisława przynoszącego owoce dla Kościoła i Polski przez całe tysiąclecie ${ }^{86}$.

To powiązanie pracy nad ubogaceniem wiary w duchu Vaticanum II z obchodem jubileuszu siedmioletniego pasterzowania i męczeńskiej śmierci św. Stanisława (1072-1079) uwidoczniło się w zwołanym w latach 19721979 Synodzie Archidiecezji Krakowskiej ${ }^{87}$. W przemówieniu na otwarciu Synodu Archidiecezji Krakowskiej 8 maja 1972 roku kard. Karol Wojtyła uzasadniał tę drogę recepcji odnowy soborowej: „Postać św. Stanisława

\footnotetext{
${ }^{84}$ Por. K. Wojtyła, U podstaw odnowy..., dz. cyt., s. 9nn.

${ }^{85}$ AKKW E III 5, s. 91-92.

${ }^{86}$ Por. Kazanie na Skatce, 14.05.1967 r., AKKW E III 4, s. 75.

${ }^{87}$ Por. AKKW E III 9, s. 5-6.
} 
[...] pojawia się już w latach siedemdziesiątych wieku XI tu w Krakowie. I zastanawiając się od lat nad znaczeniem tej postaci w dziejach naszego Chrztu, w historii chrześcijaństwa na ziemi polskiej, dochodziłem do przekonania, że wiąże się ona, poprzez św. Stanisława z momentem sakramentu bierzmowania, który to sakrament podejmuje to, co każdy z nas otrzymał w sakramencie chrztu, a zarazem pogłębia i umacnia. Tak więc Stanisław, biskup krakowski i męczennik, podjął to u początków naszych dziejów całe dziedzictwo Wojciecha, dziedzictwo chrztu. Dziedzictwem chrztu jest nade wszystko wiara. Stanisław doprowadził tę wiarę naszych przodków do pełniejszej dojrzałości [...]. I dlatego zapragnęliśmy ten historyczny wysiłek Kościoła krakowskiego w naszych posoborowych czasach związać z rocznicą św. Stanisława [...]. Tak bowiem jak on, na miarę swoich czasów, starał się doprowadzić wiarę naszych przodków do właściwej dojrzałości, tak i nam Sobór Watykański II dał wskazania, rzucił wezwanie, ażebyśmy wiarę naszą doprowadzili do takiej dojrzałości, jakiej domaga się miara naszych czasów [...] dziś jak wtedy potrzeba nam wiary mocnej, dojrzałej, świadomej, odpowiedzialnej, na miarę naszych czasów. I właśnie ku temu pragniemy skierować nasze prace, całą działalność Synodu Archidiecezji Krakowskiej, który dzisiaj się rozpoczyna"88.

W kolejnych latach uroczystych spotkań synodalnych 8 maja w katedrze wawelskiej kard. Karol Wojtyła rozwija podejmowane aktualnie tematy (rodzina, kapłaństwo itp.), ze szczególnym zwróceniem uwagi na pogłębienie świadomości dojrzałej odpowiedzialności za świadectwo wiary i jej przekaz u wszystkich wierzących. Odpowiedzialność tę najlepiej oddaje słowo „troska”, „troska pasterska”. Znalazło to wyraz w jego słowach, skierowanych w ostatnim spotkaniu do uczestników zebrania plenarnego synodu 8 maja 1978 roku w katedrze wawelskiej: „Do tej pasterskiej, twórczej troski [Sobór Watykański II] wzywa wszystkich, cały lud Boży, uznając, że Chrystus ze swoim posłannictwem: kapłańskim, prorockim, królewskim, jest źródłem posłannictwa każdego człowieka ochrzczonego. Ma więc na gruncie nauki Soboru wyrastać jakaś wspólnota twórczej troski. I ta wspólnota twórczej troski pozwoli nam, Kościołowi, przezwyciężyć wszystkie przygnębienia, frustracje. Bo ona emanuje z Serca Dobrego Pasterza. Mamy się wczuwać w rytm tego Serca, podejmować jego sens. Jesteśmy bowiem uczestnikami posłannictwa prorockiego, posłannictwa kapłańskiego, posłannictwa królewskiego i pasterskiego Chrystusa"89. Dzieło synodu w swojej metodzie, jak też i w istocie potrzebowało zaan-

\footnotetext{
${ }^{88}$ Tamże, s. 148-149.

${ }^{89}$ AKKW E III 15, s. 105.
} 
gażowania wszystkich wierzących w Kościele lokalnym. Dlatego też mogło stać się prawdziwym instrumentem recepcji Soboru.

Fundament żywotności Kościoła i jego nieustannego trudu uświęcania świata, prowadzenia ku dojrzałej wierze, w swoich kazaniach Stanisławowych widział nade wszystko kard. Karol Wojtyła w formacji kandydatów do kapłaństwa i pracy kapłanów w Kościele ${ }^{90}$. Coroczna posługa udzielania święceń subdiakonatu, diakonatu i kapłaństwa sprawowana najczęściej przy grobie św. Stanisława w katedrze wawelskiej dawała mu możliwość rozwijania istotnych wątków związanych z tymi urzędami i sakramentami. W kazaniu w czasie święceń diakonatu 8 maja 1973 roku podał zebranym myśl, że w tych święceniach „wyraża się w sposób szczególny żywotność naszego Kościoła [...] żywotność nadprzyrodzona, która swój początek i rozrost czerpie z mocy Bożej, z łaski, z tajemnicy paschalnej Jezusa Chrystusa, z obecności Ducha Świętego w Kościele, z pośrednictwa Służebnicy Pańskiej Bogarodzicy Maryi, z opieki św. Stanisława i wszystkich naszych Patronów"91. Zwracając się do kandydatów do diakonatu przypomina o podejmowanej przez nich decyzji: „Przychodzicie, ażeby powiedzieć: «tak», ażeby powiedzieć: «jestem», ażeby powiedzieć: «chcę» - na wezwanie Chrystusa, za wzorem św. Stanisława. Przychodzicie, ażeby tak właśnie powiedzieć, ażeby tak wyrazić swoją wolę, ażeby tak sformułować dojrzałość łaski powołania w Waszych młodych duszach, wobec Dobrego Pasterza, Jezusa Chrystusa i wobec dobrego pasterza św. Stanisława [...] W tej Waszej decyzji, w tej Waszej gotowości, jest może jakaś wewnętrzna śmierć, jakiś jej ślad; jakiś ślad i znamię męczeństwa: przynosicie w ofierze wasze życie”92. Takiej decyzji potrzeba, bo jak mówi kaznodzieja, „dzisiaj z tym większą siłą musi być opowiadana Ewangelia: z tym większą siłą - tak

${ }^{90}$ Cytowany wyżej cenny zbiór Kazań i przemówień kardynała Karola Wojtyly o kapłaństwie (Kraków 1995) zawiera „teksty archiwalne Kardynała z lat 1963-78 na temat istoty i natury kapłaństwa, doniosłości powołania kapłańskiego, niepowtarzalnej tożsamości kapłana i jego duchowości. Jak podkreśla redaktor książki, kapłani są przedmiotem nieustannej troski Ojca Świętego Jana Pawła II. Dlatego też w twórczości kaznodziejskiej kard. Karola Wojtyły mamy tak wiele kazań o kapłaństwie. Poruszał on ten temat w czasie święceń, podczas pielgrzymek kapłańskich urządzanych do Częstochowy i Kalwarii Zebrzydowskiej, w trakcie zjazdów kapłańskich i spotkań rocznikowych, na pogrzebach kapłanów i przy wielu innych okazjach” (K. Panuś, Zarys historii..., dz. cyt., cz. 2, s. 457). Kard. Karol Wojtyła często gromadził kapłanów czy to z racji odbywającego się soboru, obchodu milenium, czy też pracy synodu krakowskiego, gdzie wygłaszał istotne w treści konferencje czy też kazania - por. AKKW E III 1, s. 26-30.

\footnotetext{
${ }^{91}$ AKKW E III 10, s. 48.

${ }^{92}$ Tamże, s. 49.
} 
było za czasów biskupa Stanisława, kiedy ona musiała być opowiadana [...] [z] tak wielką siłą, że potrzeba była aż do śmierci Pasterza"93.

Jako biskup podejmował odpowiedzialność za swoich kapłanów. Jednym z jej przejawów była nieustanna modlitwa za nich. Tak czynił w kazaniu w czasie święceń kapłańskich 19 maja 1974 roku, kiedy prosił Maryję, aby zachowała nowo wyświęconych kapłanów aż do końca w wierności w tej liczbie, w jakiej stoją w czasie święceń przed grobem św. Stanisława ${ }^{94}$. Dwa lata później, na zjeździe rocznikowym z tymi samymi kapłanami jego homilia stała się wielką modlitwą biskupa za swoimi kapłanami na wzór Modlitwy Arcykapłańskiej Jezusa z Wieczernika ${ }^{95}$. Spełnienie się treści tej modlitwy na kapłanach stanowiło gwarancję ich owocnego posługiwania i świadectwa w świecie ${ }^{96}$.

\section{Zakończenie}

Przypomniane powyżej wątki eklezjologiczne, jakie znajdują się w kazaniach kard. Karola Wojtyły o św. Stanisławie, biskupie i męczenniku, choć nie stanowią zaplanowanej przez kaznodzieję jednolitej syntezy, moga zdumiewać zarówno swoim bogactwem, jak i głębią teologicznej treści. W lekturze poszczególnych kazań wyłaniają się jako znaki wywoławcze dla dalszych poszukiwań opisu Kościoła, jakie on pozostawił w całym swoim dziele jako arcybiskup metropolita krakowski. Kościół ten, którego jest dzieckiem, a zarazem i biskupem, jawi się w jego nauce jako wielka przestrzeń troski o zbawienie każdego człowieka. Jest to przecież podstawowy biblijny obraz Kościoła jako owczarni Jezusa Chrystusa Dobrego Pasterza przez odczytanie „znaków czasu” trafnie zastosowany do kontekstu współczesności. Tenże Kościół jako owczarnia Chrystusa podejmuje nieustanną troskę o doprowadzenie do dojrzałości wiary powierzonych sobie ludzi i jest dla tej wiary źródłem, a także - zwłaszcza w swoich świętych - pociągającym przykładem. W kazaniach Stanisławowych kard. Karola Wojtyły można dostrzec też specjalny punkt ciężkości, jakim jest odczytanie natury i misji pasterzy, tj. biskupa i związanych z nim kapłanów. Źródłem istoty ich posługi jest - przez sakrament kapłaństwa - szczególne uczestnictwo w tajemnicy zbawienia w dziele Chrystusa i Jego Kościoła. Zaś św. Stanisław staje się dla nich doskonałym komentarzem zrealizowanego życia na wzór Dobrego Pasterza.

\footnotetext{
${ }^{93}$ Tamże, s. 50.

${ }^{94}$ Por. AKKW E III 11, s. 268.

${ }^{95}$ Por. AKKW E III 13, s. 177-181.

${ }^{96}$ Por. tamże, s. 178.
} 
W swojej myśli eklezjologicznej wyrażonej w homiliach Stanisławowych kard. Karol Wojtyła podkreśla znaczenie jedności i jej istoty między Kościołami lokalnymi pomiędzy sobą, a także między Kościołami lokalnymi a Kościołem powszechnym. Doświadczenie Soboru Watykańskiego II pomogło i będzie pomagać w zgłębianiu tych bogactw dla budowania i nieustannej odnowy Kościoła Chrystusowego na ziemi. Dzieło synodu metropolitalnego, a nade wszystko w swojej archidiecezji kard. Karol Wojtyła stawia jako podstawowy środek dla gruntownego przyjęcia ogromnego bogactwa nauki Soboru Watykańskiego II. Przez naukę tego soboru dana jest Kościołowi w mocy Ducha Świętego odpowiedź na wyzwania stawiane Kościołowi przez współczesność. A synod jest potrzebny, aby tę odpowiedź rzetelnie przyswoić w Kościele lokalnym ${ }^{97}$.

Do tego dzieła synodu zapraszał nade wszystko swoich kapłanów, których chciał - przez doświadczenie Soboru Watykańskiego II, w którym czynnie uczestniczył - „zarazić” miłością do Kościoła i jego wspaniałości ${ }^{98}$. $\mathrm{Z}$ pełnym przekonaniem pisał do nich: „wspaniałe jest dzieło budowania Kościoła jako żywego organizmu dusz zespolonych prawdą i łaską Chrystusa: Jego Mistyczne Ciało. Wszystkie wartości ducha ludzkiego są w nim zawarte i przeniknione Duchem Bożym. Dlatego też każdy z nas, Bracia, musi być bardzo wrażliwy na duszę współczesnego człowieka i równocześnie bardzo czuły na działanie Ducha Świętego"

Podążając tropem historii i świadectwa św. Stanisława, biskupa i męczennika, kard. Karol Wojtyła daje świadectwo o sobie jako obdarzonym niezwykłą intuicją teologu, pasterzu i świadku, który w duchu prawdziwego pokrewieństwa ze świętym w tajemnicy communio sanctorum odczytał jego wielkość i przekazał ją nam jako niezwykłe dziedzictwo łaski Bożej działającej w historii człowieka i świata. Dlatego - jako słowo zamykające ten szkic eklezjologiczny - odczytujemy z nową aktualnością jego słowa na 900-lecie pasterzowania św. Stanisława: „Do takiego przeżycia rocznicy św. Stanisława najgoręcej wszystkich zapraszam i zachęcam. Czasy, w których żyjemy, niosą ze sobą szczególną próbę wiary. W parze z nią idzie też próba moralności, próba ludzkich charakterów. Jesteśmy wszyscy świadkami tej próby i jej uczestnikami. Mamy głębokie poczucie, że zagrożenie wiary w duszach ludzkich jest naruszeniem fundamentu, na którym wspiera się życie duchowe człowieka współczesnego, niemniej jak dawnych pokoleń [...] I oto na gruncie tego zawierzenia chcemy podejmować nadal próbę s. 103 n.

${ }^{97}$ Por. List pasterski w zwiazku z 900 rocznica św. Stanisława, „Notificationes” 1-3 (1972),

\footnotetext{
${ }^{98}$ Por. List do duchowieństwa z okazji Ingresu, art. cyt., s. 99.

${ }^{99}$ Tamże, s. 100.
} 
wiary wedle wymagań naszych czasów, tak jak podejmował ją przed dziewięciu wiekami Biskup Stanisław. W Nim też słusznie widzieliśmy patrona tej najwyższej próby. Jego życie i śmierć postawiło kiedyś przed oczyma naszych praojców oczywistość tych słów Apostoła, jakie przypomina co rok liturgia wielkanocna: «to jest zwycięstwo, które zwycięża świat, wiara nasza» $(1 \mathrm{~J} 5,4){ }^{\prime 100}$.

Kraków

KS. JÓZEF MORAWA

\section{Słowa kluczowe}

Kard. Karol Wojtyła, św. Stanisław biskup i męczennik, kazanie, homilia, Chrystus Dobry Pasterz, Kościół, lud Boży, Mistyczne Ciało Chrystusa, Kościół krakowski, wiara, świadectwo, męczeństwo, kapłan, biskup, Sobór Watykański II, Synod Archidiecezji Krakowskiej.

\section{Zusamenfassung}

\section{Die ekklesiologischen Gedanken von Kardinal Karol Wojtyła in seinen Predigten über den hl. Stanislaus, Bischof und Märtyrer}

Die homiletische Erbe von Bischof und Kardinal Karol Wojtyła aus Jahren 1958-1978 enthält 6110 maschinengeschriebenen Seiten. Leider bis heute warten sie auf eine thelogischwissenschaftliche Bearbeitung und Veröffentlichung. Unter vielen Themen, die von dem Krakauer Bischof in seinen Predigten zur Sprache gebracht wurden, gibt es auch ekklesiologische Erwägungen, die mit dem Leben und Hirtenzeugnis des hl. Stanislaus, Krakauer Bischof und Märtyrer, gebunden sind.

Der Kardinal K. Wojtyła nähert seinen Zuhörern die Bedeutung des Krakauer Märtyrers auf zwei Ebenen: historischen und theologischen. Aus beiden Ebenen kommen die belehrenden, thelogischen Inhalte, die durch die Ideen des II Watikanischen Konzils, wie auch durch das Jubiläum des 900-jährigen Hirtendienstes und Märtyriums des Bischofs Stanislaus (+ 1079) bereichert wurden. Die Kirche - nach K. Wojtyła - bedeutet eine Sorgegemeinschaft um das Heil aller Menschen, wie auch um das Reifen des Glaubens. Viele Homilien hat Kard. K. Wojtyła an die Priesteramtskandidaten gerichtet, deshalb findet man die Themen, die für das sakramentale Priestertum gelten. Die in den Krakauern Kirchen versammelten Zuhörer fanden in seinen Predigten auch mehr universalen Themen, wie das Verhältnis der Gesamtkirche zu den Einzelkirchen. Letzlich geht es dem Krakauer Kirchenhirt um die Bereicherung des Glaubens von Mitgliedern seiner Kirche, daß sie das Zeugnis vor der Welt in sich ständig verändernden Bedingungen geben können.

\section{Schlüsselworte}

Kard. Karol Wojtyła, hl. Stanislaus Bischof und Märtyrer, Predigt, Homilie, Christus Guter Hirt, Kirche, Gottes Volk, Mystischer Leib Christi, Kirche von Krakau, Glauben, Zeugnis, Martyrium, Priester, Bischof, II Vatikanisches Konzil, Synode von Krakauer Archidiözese

${ }^{100}$ List pasterski w związu z 900 rocznica św. Stanisława, dz. cyt., s. 104. 